\title{
The Determinants of Bank Performance: The Case of Tunisian Listed Banks
}

\author{
Aziz Chouikh ${ }^{1, *}$, Youssef Blagui \\ ${ }^{1}$ Department of Finance, Assistant Professor of Finance at the Mediterranean School of Business, South Mediterranean University, \\ Tunis, Tunisia, and Assistant Professor of Finance at FSJEG, University of Jendouba, Jendouba, Tunisia \\ ${ }^{2}$ Department of Finance, the Mediterranean School of Business, South Mediterranean University, Tunis, Tunisia \\ *Corresponding author: aziz.chouick@msb.tn;azizchouikh@gmail.com
}

\begin{abstract}
This paper studies the relationship between Tunisian listed banks performance and two types of determinants; internal and external. The internal explanatory variables are: (1) the bank size, (2) privatization, (3) board size, (4) capital-to-assets ratio, and (5) cost of efficiency. The macro-economic (external) exogenous variables are: (1) gross domestic product growth rate and (2) inflation. Our panel-data analyses suggest a statistically significant and negative relationship between bank profitability (endogenous variable) and board size. However, the remaining variables were found to be statistically insignificant. This can be explained by two main sub-hypotheses: (a) state-owned banks included in the sample disturb the statistical significance of the results and (b) the year 2011 is a cut-off point that changed the Tunisian bank performance determinants.
\end{abstract}

Keywords: bank performance, panel data, determinants, exogenous variable, endogenous variable

Cite This Article: Aziz Chouikh, and Youssef Blagui, "The Determinants of Bank Performance: The Case of Tunisian Listed Banks." Journal of Finance and Accounting, vol. 5, no. 2 (2017): 53-60. doi: 10.12691/jfa-5-2-4.

\section{Introduction}

Bank performance is a key lever for any country financial development. In a continuously changing environment ${ }^{1}$, understanding its determinants would act as an insurance against any risk of economic deterioration. Whether they are state-owned or private, these financial institutions play an important role in safeguarding individual's money and providing loans for investors. However, if they do not perform well, these would lead to a critical financial crisis such as the sub-prime mortgage crisis in 2008. Not only would that harm the global environment, but consequences would also last for years. In this context, having a clear idea about what causes the bank profitability would allow Tunisian banks to boost their country's economy, especially, after the revolution of 2011. In the past years, Tunisia has suffered from instable financial conditions that have pushed away investors. Consequently, bank performance has been impacted and investment projects have been blocked. This paper aims to empirically investigate the determinants of Listed Tunisian banks performance. For this purpose, we will study the impact of two types of variables: internal and macro-economic. The internal explanatory variables are: (1) the bank size, (2) privatization, (3) board size, (4) capital-to-assets ratio, and (5) cost of efficiency. The macroeconomic exogenous variables are (1) gross domestic product (GDP) growth rate and (2) inflation.

\footnotetext{
${ }^{1}$ Especially in the context of Tunisia, the environment is turbulent and marked by political unrest.
}

The remainder of this paper is organized as follows: section 2 presents the art of the empirical literature. Section 3 points out the variables. Section 4 sets up the empirical methodology. Section 5 deals with the model estimations. Section 6 copes with the results and findings. Finally, in section 7, we conclude.

\section{Literature Review}

Several studies have investigated the effect of candidate variables on bank performance. From advocates of positive relationship to supporters of inverted one, researches have still been conducted in order to put into questions the robustness of previous empirical results. In addition, the bank performance topic has been an interesting topic in developed as well as in developing countries. For instance, Ongore and Kusa [49] investigated the determinants of bank performance in Kenya, Royfaizal and Fadzlan [54] in the Philippines, Schelagh and Maggie [57] in China, Togbenou and Combey [62] in Togo, Tomuleasa [63] in Europe, Trabelsi [64] in Tunisia, and Tumin and Said [65] in Malaysia and China. The huge body of the empirical literature has related the bank performance to internal as well as external determinants. Pradhan \& Shrestha [52], Aladawan [2], Bourke [17], Srairi [60], and Bikker \& Hu [16] found an empirical positive relationship between bank size and bank profitability, especially in the case of a large size. Yet Terraza [61] empirically supported this significantly positive relationship only for medium sized banks. These findings were questioned by the findings made by Batten and Vinh [5], Kosmidou et al [41] and 
Boyd and Runkle [19], Berger et al [13], Saddique et al [55]. Their findings suggested a significantly negative relationship. An empirical research made by Kasman [37] over more than 400 banks significantly evidenced the negative relationship between the net interest $\operatorname{margin}^{2}$ and bank size. This is in line with the inverted U-curve theory which suggests a convex relationship between bank size and its profitability. However, Kagecha [36] evidenced that the bank size does not matter. The portfolio theory suggests that there is a direct link between bank return and decisions made by executives. In fact, Pasiouras et al [51] studied the relationship between bank efficiency and stock returns. Most of the papers that have studied the subject support the evidence that both variables are negatively linked such as Yermack [67], Eisenberg et al [26], Jensen [35], Guest [32], and Fanta et al [27]. They believe that the higher is the number of directors, the lower is the performance of the firm. This is mainly due to the fact that a large board does not favor a good communication process. Consequently, decisions made by the executives would not be effective. That would lead to poor performance results. However, empirical investigations made on the banking sector empirically pointed out the opposite. Some researchers, such as Ben Amar and Abaoub [9], Ben Arab and Riahi [10], and Ben Gamra et al [11], have related bank profitability to earnings management. A research made by Belkhir [8] over more than 170 US banks revealed that large boards and bank performance are positively correlated. The result questions the statement made by Lipton and Lorch [42]. Both supported the idea that a smaller board of directors leads to higher effectiveness and thus better firm performance. Moreover, Khalfaoui and Ben Saada [39] evidenced that credit risk, liquidity, total assets, and disclosure of information related to credit are the main determinants of banking profitability.

The bank capital theory suggests that banks are able to survive with higher capital and less liquidity (Diamond and Rajan [24]). Several empirical studies have been made about this positive relationship. In addition, empirical evidence has also been reported about the positive relationship between the return on equity and capital-to-asset ratio. Another study made by Abreu and Mendes [1] showed that European banks with higher capital performed better than competitors with lower one. Not only could they face bankruptcy risk, but also they could rely much less on external funding sources. Similar studies supported the same findings such as Abreu \& Mendes [1], Liu et al [43], Bourke [17], and Goddard et al [30]. However, researchers Hughes and Mester [33] found antagonist results. In fact, they found that higher capital-to-assets ratio results in increased variable costs, which do not really translate in higher profitability. Furthermore, Clementina and Isu [21] consistently reported that improved capital position enhances the bank performance.

Economic literature, theoretical as well as empirical, has connected the performance of banks to competition, concentration, efficiency, productivity, and profitability (See Jaap and Bikker [34]). The economic theory indicates

\footnotetext{
${ }^{2}$ Net interest margin is a performance ratio that evaluates the goodness of investment considering the debt amount of a firm. It is equal to the difference between investment return and Interest expenses divided by the average earnings assets.
}

an inverted relationship between bank profitability and efficiency cost. However, empirical researches suggest antagonist results. An empirical study made by Košak and Zajc [40] proved that there is a positive relationship between the two variables when it comes to banks belonging to European Union. Similar researches made by Sanchez et al [56], Kasman \& Carvallo [38], and Berger and Mester [15] pointed out the same findings. Banks with better cost of efficiency tend to optimize the allocation of their resources, which results in higher income.

The Productive Efficiency theory suggests that privateownership lead to the implementation more efficient policies. The effect of this variable has been tackled by several researchers such as Makhoha [44] and Beck et al [6]. The latter studied the effect of a private ownership over Nigerian Banks. For this objective, they collected annual data of more than 68 banks. They decided to cover a period of 11 years which led to more than 500 observations. Results showed that privatized banks were more performing. Similar studies performed by Dietrich and Wanzenried [25] over Swiss banks support the same findings. However, they empirically proved the negative impact of private-ownership on banks performance following the study of more than 115 countries.

Investigators such as Ben Naceur and Ghazouani [12] and Umar et al [66] were in favor of an inverse link between the inflation and bank performance. The more inflation increases, the less the banking sector shows positive results and vice versa. This conclusion has been made after a panel data study over 11 countries from the MENA $^{3}$ regions. Similarly, Boyd et al [18] evaluated the effect on inflation of banking belonging to more than 95 countries. To do so, they collected data that cover a period of 35 years. Their panel data estimation led to the statistical evidence of a negatively significant relationship. Nevertheless, Clementina et al [22] found out a positive but statistically insignificant relationship between inflation and bank performance. Other studies made by Naceur and Kandil [47] evidenced the same empirical results. However, this outcome was empirically rejected by authors such as Molyneux and Thornton [45], Pasiouras and Kosmidou [50], and Revell [53]. In addition, researchers such as Asutay and Izhar [4] collected data about a sample of Indonesian Islamic banks and regressed the dependent variable, which was return on assets (ROA), on the independent variable inflation. As a result, they found out that inflation has a positive impact on these bank profitability measures.

Economic theory suggests a positive relationship between economic growth and bank profitability (Calza et al, [20]). Murad et al [46] empirically founded out a statistically significant relationship between bank performance and interna and external determinants. Besides, it was associated positively with bank performance by Beckmann [7], Goddard et al [31], and Arpa et al [3]. They believe that an increase GDP would increase the consumer purchasing power. As a consequence, people would tend to get more credits and invest on a higher frequency. That would result in an increase of cash inflow leading to better bank performance.

\footnotetext{
${ }^{3}$ Middle East North Africa.
} 


\section{The Variables}

\subsection{The Endogenous Variables}

We deal with three dependent variables that are used as proxies of the bank performance. corresponding author. corresponding author.

\subsubsection{Return on Assets (ROA)}

Most of literatures refer to the return on asset (ROA) as a measure of bank profitability. Researchers such as Nippani and Green [48] that validated its usefulness in having an approximation of bank profitability. Furthermore, it has been used by Beck et al [6] to estimate the profitability of Nigerian banks as well as Asutay and Izhar [4] to evaluate Indonesian bank performance. It is measured by the ratio Net income to Total assets. It shows the profit earned per 1 dinar of assets. In other words, it is an indicator of how well a bank uses it assets in order to generate profit. ROA can be directly derived from bank's financial statements or calculated using the ratio stated above.

\subsubsection{Return on Equity (ROE)}

Return on equity is considered by most of the literatures in order to calculate the bank performance. For instance, It has been used by Berger and Humphrey [14], Ganesan [29], Fries and Taci [28], and De Young and Rice [23]. It is measured by the ratio of net income to stockholder equity. This ratio shows the profit earned per 1 dinar of investment. It is an indicator of how well bank uses investors' money to generate profit. ROE can be directly derived from bank's financial statements or calculated using the ratio stated above.

\subsubsection{Price to Book Ratio (PB)}

It is equal to the ratio of market stock close price to book value per share. It is done on an annual basis meaning that the close price is taken on December $31^{\text {st }}$ of each year. A ratio lower than 1 indicates a value destruction; however, a ratio greater than 1 means a value creation.

These explained variables are summarized in the table below.

\begin{tabular}{|c|c|c|}
\hline Bank Performance proxy & Acronym & Formula \\
\hline Return on Assets & ROA & Net income/Total assets \\
\hline Return on Equity & ROE & $\begin{array}{l}\text { Net income/Shareholder's } \\
\text { equity }\end{array}$ \\
\hline Price to Book & PB & $\begin{array}{c}\text { Market price }{ }^{4} \text { /Book value } \\
\text { per share }\end{array}$ \\
\hline
\end{tabular}

\subsection{The Exogenous Variables}

They can be split into two categories: internal and macroeconomic (i.e. external) variables. We cope with

\footnotetext{
${ }^{4}$ The market price used to calculate the price to book ratio is the close price on December $31^{\text {st }}$.

${ }^{5}$ The book value per share (BVPS) is calculated as follows: (Total assets-Total liabilities)/Total number of shares outstanding.
}

five internal explanatory variables, while the macroeconomic variables are two.

\subsubsection{Internal Exogenous Variables}

Five exogenous variables specific to the banks are chosen. The first one is the board of size (Bos) which is measured by the number of directors that are officially board members. Then, the bank size (Bs), which is measured by the logarithm of total assets, will be used. Furthermore, we will refer to the cost of efficiency (Ceff) which is equal to the ratio of overhead cost to bank total assets. In addition, private-ownership (Priv) will be considered. It is a dummy variable that is equal to 1 when the bank is private and 0 when the bank is state-owned. Finally, the capital to assets ratio (Car), which is equal to the capital over Total Assets, will be included.

\subsubsection{External Exogenous Variables}

The first one is the GDP growth rate (Gdp). The corresponding data are collected directly from the World Bank data. Concerning the second one, it is the annual inflation rate (Inf). Data provided by the World Bank also will be relied on.

All the explanatory variables are summarized in the tables below:

Table 2. List of Bank Performance Determinants

\begin{tabular}{|c|c|c|c|}
\hline $\begin{array}{l}\text { Explanatory } \\
\text { variable }\end{array}$ & Type & Acronym & Formula \\
\hline Board size & Internal & Bos & $\begin{array}{l}\text { Number of directors that are } \\
\text { officially board members }\end{array}$ \\
\hline Bank Size & Internal & Bs & $\begin{array}{c}\text { Neperian logarithm of total } \\
\text { assets }\end{array}$ \\
\hline $\begin{array}{l}\text { Cost of } \\
\text { efficiency }\end{array}$ & Internal & Ceff & Overhead/Total Assets \\
\hline $\begin{array}{l}\text { Private- } \\
\text { ownership }\end{array}$ & Internal & Priv & $\begin{array}{l}\text { equals to } 1 \text { when the bank is } \\
\text { private and } 0 \text { when the bank is } \\
\text { state-owned }\end{array}$ \\
\hline $\begin{array}{l}\text { Capital-to- } \\
\text { assets }\end{array}$ & Internal & Car & Capital/Total Assets \\
\hline
\end{tabular}

Table 3. List of Bank Performance Determinants

\begin{tabular}{cccc}
\hline Explanatory variable & Type & Acronym & Formula \\
\hline GDP growth rate & External & Gdp & $\begin{array}{c}\text { Data Collected from } \\
\text { World Bank }\end{array}$ \\
Inflation & External & Inf & $\begin{array}{c}\text { Data Collected from } \\
\text { World Bank }\end{array}$ \\
\hline
\end{tabular}

\section{The Empirical Methodology}

\subsection{Data}

One of the main goals of this empirical research is to cover the longest period. However, the available information could be collected only beginning from 1997. As a consequence, the final period that will be studied extends from 1997 to 2015. Information is available for the target listed Tunisian banks, only for Attijari bank. For this reason, it will be excluded from the sample even though it is a major player of the Tunisian banking sector. The final sample is constituted of 7 private banks (Amen Bank, ATB, UBCI, UIB, BT, BTE and BIAT) and 3 state- 
owned banks (STB, BNA and BH). Taking into account the prerequisites of the research, empirical analyses will include 10 Tunisian banks listed in Tunisian Stock Exchange over 18 years. Consequently, our panel data consist of 10 individuals with yearly data for a 18-year period.

\subsection{Descriptive Statistics}

On average, the number of directors in the board is equal to 11.015 per bank. The maximum number of director per bank is equal to 14 against a minimum of 5 . The board is composed of 12 directors in $50 \%$ of the observations.

On average, the bank size is equal to 11.315 Million dinars. Among the studied banks, the highest value is equal to 22.143 Million Dinars against a lowest value of 5.686 Million Dinars.

On average, the capital to asset ratio is equal to $17.6 \%$. Among the studied banks, the highest value of the ratio is equal to $10.096 \%$ against a lowest value of $-14.13 \%$.

On average, the cost of efficiency ratio is equal to 0.301 . Amongst the studied banks, the highest value of the ratio is equal to $54.29 \%$ against a lowest value of $-3.124 \%$.

From 1997 to 2015, the average GDP growth rate is equal to $3.8 \%$. During this period, it reached a highest value of $6.71 \%$ against a lowest value of $-1.91 \%$.

From 1997 to 2015, the average inflation rate is equal to $4.17 \%$. This variable reached a highest value of $14.12 \%$ against a lowest value of $2.107 \%$.

\subsection{The Methodology}

Based on the previous empirical literature, seven hypotheses are pointed out, then they will be tested. The first hypothesis (H1) states the negative and significant statistical relationship between bank profitability and Bos. Through the second hypothesis, we will statistically test the positive and significant correlation between bank profitability and Bs (H2). Furthermore, we will check the validity of the positive and significant statistical relationship between Ceff and bank performance (H3). Moreover, we will test the positive and significant correlation of Car with bank profitability (H4). Besides, the assumption that Priv is positively and significantly correlated to the bank performance will be investigated (H5). In addition, the positive and significant link between GDP and bank profitability will be tested (H6). Finally, we will check whether or not inflation negatively and significantly affects the bank performance (H7).

The hypothesis is completely accepted if the coefficient estimate is statistically significant and its sign is as predicted. It is partially accepted if the coefficient estimate is not statistically significant; however, its sign is as predicted. Otherwise, the hypothesis is rejected.

The hypotheses, mentioned above, are summed up in the table below.

To do so, a static panel-data regression will be set up. Within the model regression, the bank performance measure proxy is the endogenous variable. It follows that we will estimate three models given that we deal with three bank profitability measures.
Table 4. Hypotheses

\begin{tabular}{|c|c|}
\hline Hypothesis & Description \\
\hline H1 & $\begin{array}{l}\text { Profitability is negatively and significantly linked to board } \\
\text { size }\end{array}$ \\
\hline $\mathrm{H} 2$ & $\begin{array}{l}\text { Profitability and bank size are positively and significantly } \\
\text { correlated }\end{array}$ \\
\hline $\mathrm{H} 3$ & $\begin{array}{l}\text { Cost of efficiency positively and significantly impacts } \\
\text { bank performance }\end{array}$ \\
\hline H4 & $\begin{array}{l}\text { Capital-to-asset ratio is positively and significantly } \\
\text { correlated to bank performance }\end{array}$ \\
\hline H5 & $\begin{array}{l}\text { Privatization positively and significantly impact bank } \\
\text { profitability }\end{array}$ \\
\hline H6 & $\begin{array}{l}\text { GDP and bank performance are positively and } \\
\text { significantly linked }\end{array}$ \\
\hline $\mathrm{H} 7$ & $\begin{array}{l}\text { Inflation negatively and significantly impacts bank } \\
\text { performance }\end{array}$ \\
\hline
\end{tabular}

\section{The Model Regressions}

Our linear model aims at estimating the relationship between the dependent variable (bank performance) and the independent variables (internal and macroeconomic). The general model is estimated by the following regression equation:

$$
\begin{aligned}
& \text { PERF }_{i t}=\beta_{0}+\beta_{1}\left(\text { Bs }_{i t}\right)+\beta_{2}\left(\text { Bos }_{i t}\right)+\beta_{3}\left(\text { Ceff }_{i t}\right) \\
& +\beta_{4}\left(\text { Priv }_{i t}\right)+\beta_{5}\left(\text { Car }_{i t}\right)+\beta_{6}\left(G d p_{t}\right)+\beta_{7}\left(\operatorname{Inf}_{t}\right)+\varepsilon_{i t}
\end{aligned}
$$

Where PERF $_{i t}$ is the performance measure of the $i^{\text {th }}$ individual at time $t$. This dependent variable will be measured by: ROA, ROE, and $\mathrm{PB}, \beta_{0}$ is the intercept (the constant of the model) and $\beta_{\mathrm{k}}, \mathrm{k}=1, \ldots, 7$ are the coefficients to be estimated, and $\varepsilon_{i t}$ is the error term. A significantly positive coefficient estimate signifies a statistically significant positive relationship between the bank profitability and the corresponding determinant. In contrast, a significantly negative coefficient estimate signifies a statistically significant negative relationship between the bank performance and the corresponding determinant.

Indeed, since three performance proxies are taken, we will have three models to estimate. Each model will be estimated using static panel-data estimation method. For each model regression, the random effect (RE) vs the fixed effect (FE) will also be tested via the Hausman test ${ }^{6}$.

\subsection{Model 1}

The first model will study the statistical relationship between the dependent variable ROA and the seven candidate exogenous variables. Its equation is as follows:

$$
\begin{aligned}
& R O A_{i t}=\alpha_{0}+\alpha_{1}\left(\mathrm{Bs}_{i t}\right)+\alpha_{2}\left(\operatorname{Bos}_{i t}\right)+\alpha_{3}\left(\text { Ceff }_{i t}\right) \\
& +\alpha_{4}\left(\text { Priv }_{i t}\right)+\alpha_{5}\left(\text { Car }_{i t}\right)+\alpha_{6}\left(G d p_{t}\right)+\alpha_{7}\left(\operatorname{Inf} f_{t}\right)+n_{i t}
\end{aligned}
$$

\subsection{Model 2}

The second model will test the statistical relationship between the dependent variable ROE and the seven candidate independent variables. Its equation is as follows:

\footnotetext{
${ }^{6}$ We use EViews to run the underlying regresion equation estimations and related tests.
} 


$$
\begin{aligned}
& R O E_{i t}=\delta_{0}+\delta_{1}\left(\mathrm{Bs}_{i t}\right)+\delta_{2}\left(\operatorname{Bos}_{i t}\right)+\delta_{3}\left(\operatorname{Ceff}_{i t}\right) \\
& +\delta_{4}\left(\operatorname{Priv}_{i t}\right)+\delta_{5}\left(\text { Car }_{i t}\right)+\delta_{6}\left(G d p_{t}\right)+\delta_{7}\left(\operatorname{Inf}_{t}\right)+u_{i t} .
\end{aligned}
$$

\subsection{Model 3}

The third model will assess the statistical relationship between the endogenous variable $\mathrm{PB}$ and the seven candidate explanatory variables. Its equation is as follows:

$$
\begin{aligned}
& P B_{i t}=\gamma_{0}+\gamma_{1}\left(\mathrm{Bs}_{i t}\right)+\gamma_{2}\left(\text { Bos }_{i t}\right)+\gamma_{3}\left(\text { Ceff }_{i t}\right) \\
& +\gamma_{4}\left(\text { Priv }_{i t}\right)+\gamma_{5}\left(\text { Car }_{i t}\right)+\gamma_{6}\left(G d p_{t}\right)+\gamma_{7}\left(\operatorname{Inf}_{t}\right)+v_{i t} .
\end{aligned}
$$

\section{Empirical Results and Findings}

For the first model as described by equation (2), we run the Hausman test. As shown, in the Table 5 below, the $\mathrm{p}$-value is equal to 0.1666 . It follows that we do not reject the null hypothesis that there is no misspecification. Consequently, the model 1 will be estimated using the RE.

Table 5. Hausman test for Model 1

\begin{tabular}{cccc}
\hline Test Summary & Chi-Sq. Statistic & Chi-Sq. d.f & P-value \\
\hline Cross-section random & 6.472198 & 4 & 0.1666 \\
\hline
\end{tabular}

As shown, in Table 6 below, the estimation of the underlying model 1 leads to the following results.

Table 6. Model 1 Estimation using RE

\begin{tabular}{ccccc}
\hline Variable & $\begin{array}{c}\text { Coefficient } \\
\text { estimate }\end{array}$ & $\begin{array}{c}\text { Standard } \\
\text { error }\end{array}$ & t-statistic & P-value \\
\hline Constant & 0.016095 & 0.031049 & 0.518365 & 0.6048 \\
Bs & -0.000527 & 0.001178 & -0.447434 & 0.6551 \\
Bos & -0.001168 & 0.002520 & -0.463473 & 0.6436 \\
Ceff & 0.000265 & 0.000952 & 0.277969 & 0.7814 \\
Priv & 0.021454 & 0.013479 & 1.591640 & 0.1132 \\
Car & 0.000787 & 0.005115 & 0.153790 & 0.8779 \\
Gdp & -0.000684 & 0.001909 & -0.358137 & 0.7207 \\
Inf & 0.000503 & 0.001542 & 0.326122 & 0.7447 \\
\hline
\end{tabular}

According to the model estimation output above, all the explanatory variables, in model 1 , are statistically insignificant given that all p-values are greater than $10 \%$. The intercept (the constant) is also statistically not significant. The model 1 is globally and statistically insignificant. Therefore, the ROA as a proxy of the bank performance is not statistically explained by the underlying candidate determinants. However, some coefficient estimate signs are in line with the corresponding hypotheses. It follows that some hypotheses are partially accepted. In fact, Bos, Ceff, Car, and Priv are not statistically significant, but their coefficient estimate signs are as predicted by the hypotheses, respectively, $\mathrm{H} 1, \mathrm{H} 3, \mathrm{H} 4$, and $\mathrm{H} 5$. We recapitulate, in the Table 7 below, the rejected and partially accepted hypotheses.

For the second model as described by equation (3), we run the Hausman test. As shown, in the Table 8 below, the $\mathrm{p}$-value is equal to 0.6042 . It follows that we do not reject the null hypothesis that there is no misspecification. Consequently, the model 2 will be estimated using the RE.

Table 7. Summary of the Hypothesis Acceptance or Rejection: Model 1

\begin{tabular}{cccc}
\hline Determinant & $\begin{array}{c}\text { Statistical } \\
\text { significance }\end{array}$ & $\begin{array}{c}\text { Coefficient } \\
\text { estimate sign }\end{array}$ & $\begin{array}{c}\text { Hypothesis confirmed, } \\
\text { partially confirmed, or } \\
\text { rejected }\end{array}$ \\
\hline Bs & Insignificant & Negative & H2 rejected \\
Bos & Insignificant & Negative & H1 partially confirmed \\
Ceff & Insignificant & Positive & H3 partially confirmed \\
Priv & Insignificant & Positive & H5 partially confirmed \\
Car & Insignificant & Positive & H4 partially confirmed \\
Gdp & Insignificant & Negative & H6 rejected \\
Inf & Insignificant & Positive & H7 rejected \\
\hline
\end{tabular}

Table 8. Hausman test for Model 2

\begin{tabular}{cccc}
\hline Test Summary & Chi-Sq. Statistic & Chi-Sq. d.f & P-value \\
\hline Cross-section random & 2.728906 & 4 & 0.6042 \\
\hline
\end{tabular}

As shown, in Table 9 below, the estimation of the underlying model 2 leads to the following results.

Table 9. Model 2 Estimation using RE

\begin{tabular}{ccccc}
\hline Variable & $\begin{array}{c}\text { Coefficient } \\
\text { estimate }\end{array}$ & $\begin{array}{c}\text { Standard } \\
\text { error }\end{array}$ & t-statistic & P-value \\
\hline Constant & 0.286696 & 0.058149 & 4.930376 & 0.0000 \\
Bs & -0.004115 & 0.001906 & -2.159345 & 0.0321 \\
Bos & -0.015161 & 0.004754 & -3.188825 & 0.0017 \\
Ceff & -0.000675 & 0.001951 & -0.345856 & 0.7299 \\
Priv & 0.016655 & 0.019856 & 0.838792 & 0.4027 \\
Car & -0.002012 & 0.010452 & -0.192503 & 0.8476 \\
Gdp & -0.001972 & 0.003920 & -0.503236 & 0.6154 \\
Inf & 0.006084 & 0.003184 & 1.910863 & 0.0576 \\
\hline
\end{tabular}

According to the model estimation output above, the intercept (the constatnt), Bs, Bos, and Inf are statistically significant, respectively, at $1 \%, 5 \%, 1 \%$, and $10 \%$ level. However, only the Bos coefficient estimate has a sign in line with its corresponding hypothesis. The model 2 is globally and statistically significant. As a result, the ROE as a bank profitability measure is statistically explained by Bs, Bos, and Inf. We recapitulate, in the Table 10 below, the accepted, partially accepted, and rejected hypotheses.

Table 10. Summary of the Hypothesis Acceptance or Rejection: Model 2

\begin{tabular}{cccc}
\hline Determinant & $\begin{array}{c}\text { Statistical } \\
\text { significance }\end{array}$ & $\begin{array}{c}\text { Coefficient } \\
\text { estimate sign }\end{array}$ & $\begin{array}{c}\text { Hypothesis confirmed, } \\
\text { partially confirmed, or } \\
\text { rejected }\end{array}$ \\
\hline Bs & Significant & Negative & H2 partially confirmed \\
Bos & Significant & Negative & H1 confirmed \\
Ceff & Insignificant & Negative & H3 rejected \\
Priv & Insignificant & Positive & H5 partially confirmed \\
Car & Insignificant & Negative & H4 rejected \\
Gdp & Insignificant & Negative & H6 rejected \\
Inf & Significant & Positive & H7partially confirmed \\
\hline
\end{tabular}


For the last model as described by equation (4), we run the Hausman test. As shown, in the Table 11 below, the p-value is equal to 0.6270 . It follows that we do not reject the null hypothesis that there is no misspecification. Consequently, the model 3 will be estimated using the RE.

Table 11. Hausman test for Model 3

\begin{tabular}{cccc}
\hline Test Summary & Chi-Sq. Statistic & Chi-Sq. d.f & P-value \\
\hline Cross-section random & 2.599107 & 4 & 0.6270 \\
\hline
\end{tabular}

As shown, in Table 12 below, the estimation of the underlying model 3 leads to the following results.

Table 12. Model 3 Estimation using RE

\begin{tabular}{ccccc}
\hline Variable & $\begin{array}{c}\text { Coefficient } \\
\text { estimate }\end{array}$ & $\begin{array}{c}\text { Standard } \\
\text { error }\end{array}$ & t-statistic & P-value \\
\hline Constant & 4.949731 & 1.071563 & 4.619170 & 0.0000 \\
Bs & 0.010608 & 0.034237 & 0.309838 & 0.7570 \\
Bos & -0.332601 & 0.087571 & -3.798054 & 0.0002 \\
Ceff & -0.008546 & 0.036551 & -0.233817 & 0.8154 \\
Priv & 0.659112 & 0.352865 & 1.867886 & 0.0634 \\
Car & -0.148168 & 0.195691 & -0.757150 & 0.4499 \\
Gdp & -0.114154 & 0.073513 & -1.552836 & 0.1222 \\
Inf & -0.060321 & 0.059760 & -1.009387 & 0.3141 \\
\hline
\end{tabular}

According to the model estimation output above, the intercept (the constant), Bos, and Priv are statistically significant, respectively, at $1 \%, 1 \%$, and $10 \%$ level. In addition the Bos and Priv signs are as expected to be. the model 3 is globally and statistically significant. Consequently, the PB as a bank performance proxy is significantly explained by Bos and Priv. We recapitulate, in the Table 13 below, the accepted, partially accepted, and rejected hypotheses.

Table 13. Summary of the Hypothesis Acceptance or Rejection: Model 3

\begin{tabular}{cccc}
\hline Determinant & $\begin{array}{c}\text { Statistical } \\
\text { significance }\end{array}$ & $\begin{array}{c}\text { Coefficient } \\
\text { estimate sign }\end{array}$ & $\begin{array}{c}\text { Hypothesis confirmed, } \\
\text { partially confirmed, or } \\
\text { rejected }\end{array}$ \\
\hline Bs & Insignificant & Positive & H2 partially confirmed \\
Bos & Significant & Negative & H1 confirmed \\
Ceff & Insignificant & Negative & H3 rejected \\
Priv & Significant & Positive & H5 confirmed \\
Car & Insignificant & Negative & H4 rejected \\
Gdp & Insignificant & Negative & H6 rejected \\
Inf & Insignificant & Negative & H7partially confirmed \\
\hline
\end{tabular}

Amongst the estimated three models, we eliminate the first one because it is statistically and globally insignificant. The remaining models are models 2 and 3 wherein, respectively, the bank performance is measured by ROA and PB. Our selection criterion is the adjusted- $\mathrm{R}^{2}$. Model 2 has an adjusted- $\mathrm{R}^{2}$ equal to 0.054705 , while model 3 has an adjusted- $\mathrm{R}^{2}$ equal to 0.095595 . As a matter of fact, we choose the model 3 because it has the greatest adjusted- $\mathrm{R}^{2}$.

Given that our sample consists of private and state-owned banks as well and it covers a period from 1997 to 2015 where 2011 (the year of revolution) is inside the sample period, we suspect that the presence of state-owned banks in our sample disturbs our empirical results (sub-hypothesis $\mathrm{Ha}$ ), and so does the year 2011 (sub-hypothesis Hb). Thus, we re-estimate the models excluding the state-owned banks from our initial sample, and we run the same models for the sub-periods: before 2011 and after 2011.

Starting with the second model, the explanatory variable Bos becomes statistically insignificant when we remove the state-owned banks from our sample. It also becomes reliably insignificant following the cut-off point year 2011. Consequently, both hypotheses $\mathrm{Ha}$ and $\mathrm{Hb}$ are empirically confirmed. Moving to the third model, the independent variable Bs becomes statistically significant after the breaking point 2011, which confirms H3.

All in all, after testing our two sub-hypotheses $\mathrm{Ha}$ and $\mathrm{Hb}$, we point out the following empirical results: (a) stateowned banks included in the sample disturb the statistical significance of the results and (b) the year 2011 is a cutoff point that changed the Tunisian bank performance determinants

\section{Conclusion}

Based on our empirical findings, the explanatory variable Bos is found out to be statistically and negatively correlated to the bank performance measured by ROE and PB within panel-data model regressions using random effects (RE). In fact, the more number of officials are present in the board of directors, the lower is the bank performance and vice versa. Consequently, Tunisian quoted banks should reconsider their governance structure. From the descriptive statistics, we report that the average number of directors is equal to almost 11 . Instead of leading to wiser decision making, a larger board would result in ineffective initiatives. Based on our analysis, Following the cut-off point 2011, the determinants of Tunisian listed banks changed in terms of statistical significance and coefficient sign. Therefore, it is fundamental for these financial institutions to take into account this fact whenever conducting a performance analysis that covers a period prior or including the breaking point year 2011. In case of performance determinants considered individually has not changed, it is important to update them using data starting from the year 2012. Starting from 2012, the explanatory variable Bs becomes statistically significant and is positively correlated to bank performance. It means that the higher is the bank size the better is the bank performance. Therefore, directors should engage in better procedures in order to raise the value of their total assets. This further confirms the literature of Spathis et al [59] who investigated the effect of large bank size on Greek bank profitability from 1990 to 1999. They found that both had a positive relationship. Finally, the exogenous variable Priv is evidenced to be statistically significant and positively correlated to bank performance. Therefore, State-owned banks should reconsider the option of being privatized, especially that we evidenced their disturbance effect on our studied sample. 


\section{Acknowledgements}

We would like to thank an anonymous referee for helpful comments and criticism. We also owe a great deal of gratitude to those who have helped us along this research.

\section{References}

[1] Abreu M. and V. Mendes. (2002). Commercial bank interest margins and profitability: evidence from E.U countries. Porto Working paper series.

[2] Aladwan, S. M. (2015). The Impact of bank Size on profitability: An Empirical Study on Listed Jordanian Commercial Banks. European Scientific Journal December 2015 edition vol.11, No.34.

[3] Arpa, M., Giulini, I., Ittner, A., \& Pauer, F. (2001). The influence of macroeconomic developments on Austrian banks: implications for banking supervision, Basel, Bank for International Settlements, BIS Paper, No. 1.

[4] Asutay, M., \& Izhar, H. (2007). Estimating the Profitability of Islamic Banking: Evidence from Bank Muamalat Indonesia. Review of Islamic Economics, Vol. 11, No. 2, 2007.

[5] Batten, A. J., \& Vinh, X. Vo. (2013). Determinants of Bank Profitability - Evidence from Vietnam. Department of Banking \& Finance, Monash University, Caulfield Campus.

[6] Beck, Thorsten, Robert Cull, \& Afeikhena Jerome. (2005). Bank Privatization and Performance: Empirical Evidence from Nigeria. Journal of Banking and Finance 29, 2355-2379.

[7] Beckmann, R. (2007). Profitability of Western European banking systems: Panel Evidence on structural and cyclical determinants. Series 2: Banking and Financial Studies. No. 17, 2007.

[8] Belkhir, M. (2008). Board of Directors' Size and Performance in the Banking Industry. International Journal of Managerial Finance, Vol. 5, No. 1, 2009.

[9] Ben Amar, A., \& Abaoub, E. (2010). Earnings Management Thresholds: The Case in Tunisia. AAMJAF, Vol. 6, No. 2, 35-56, 2010.

[10] Ben Arab, M., \& Riahi, Y. (2011). Disclosure Frequency and Earnings Management: Analysis in the Tunisian context. Journal of Accounting and Taxation Vol. 3(3), pp. 47-59, July 2011.

[11] Ben Gamra, S., Homrani, K., \& Abouab, E. (2013). The Determinants of Earnings Management: Empirical Evidence in the Tunisian Banking Industry (1999-2010). Journal of Business Studies Quarterly 2013, Volume 4, No.3.

[12] Ben Naceur, S \& Ghazouani, S. (2005). Does Inflation Impact on Financial Sector Performance in the MENA Region? Panel Data Evidence. Working paper. http://.ssrn.com/abstract=856344.

[13] Berger, A., Hanweck, G. and Humphrey, D. (1987). Competitive viability in banking: Scale, scope and product mix economies. Journal of Monetary Economics 20, 501-520.

[14] Berger, A., and Humphrey, D. (1997). Efficiency of financial institutions: international survey and directions for future research. European Journal of Operational Research 98, 175-212.

[15] Berger, A., Mester, L.J. (2003). Explaining the dramatic changes in performance of US banks: technological change, deregulation and dynamic changes in competition. Journal of Financial Intermediation, 12, 57-95.

[16] Bikker, J.A. and H. Hu. (2002). Cyclical Patterns in Profits, Provisioning and Lending of Banks and Procyclicality of the New Basle Capital Requirements. BNL Quarterly Review, 221, pp. 143-175.

[17] Bourke, P. (1989). Concentration and other determinants of bank profitability in Europe, North America and Australia. Journal of Banking \& Finance, 13(1), 65-79.

[18] Boyd, J. H., Levine, R., \& Smith, D. B. (2000). The Impact of Inflation on Financial Sector Development. Journal of Economic Literature E31, pp. 1-19.

[19] Boyd, J.H., Runkle, D.E. (1993). Size and Performance of Banking Firms: Testing the Predictions of Theory. Journal of Monetary Economics 31, 47-67.

[20] Calza, A., Manrique, M., \&Sousa, J. (2006). Credit in the euro area: An empirical investigation using aggregate data. The Quarterly Review of Economics and Finance, 46(2), 211-226.

[21] Clementina, K., \& Isu, O. H. (2013). The Impact of Capitalization on Bank Performance in Nigeria 1970-2010: An Assessment.
International Review of Management and Business Research Vol. 2 Issue. 3.

[22] Clementina, O. N., Adanma, E. S., \& Chioma, O. D. (2014). Empirical Study of the Impact of Inflation on Bank Performance: Implication for Investment Decision Making in Banking Industry in Nigeria. Humanity \& Social Sciences Journal 9 (2): 61-71, 2014

[23] DeYoung, R., Rice, T. (2004). Non-interest income and financial performance at US commercial banks. The Financial Review, vol. 39, pp. 101-127.

[24] Diamond, W. D., \& Rajan, G. R. (1999). A Theory of Bank Capital. Working paper 431.

[25] Dietrich, A., Wanzenried, G. (2011). Determinants of bank profitability before and during the crisis: evidence from Switzerland. Journal of International Financial Markets, Institutions and Money, 21(3), 307-327.

[26] Eisenberg, T., Sundgren, S., Wells, M.T. (1998). Larger board size and decreasing firm value in small firms. Journal of Financial Economics, 48(1), 35-54.

[27] Fanta, B. A., Kemal, S. K., \& Waka,K. Y. (2013). Corporate Governance and impact on Bank Performance. Journal of Finance and Accounting. Vol. 1, No. 1, 2013, pp. 19-26.

[28] Fries, S., \& Taci, A. (2004). Cost efficiency of banks in transition: Evidence from 289 banks in 15 post-communist countries. Journal of Banking and Finance, 29, 55-81.

[29] Ganesan, P. (2001). Determination of profits and profitability of public section banks in India: A profit function. Journal of Financial Management and Analysis, 14(1), 27-37.

[30] Goddard, J., Molyneux, P., \& Wilson, J. O. S. (2004). The profitability of european banks: a cross-sectional and dynamic panel analysis. The Manchester School, 72(3), 363-381.

[31] Goddard, J., Molyneux, P. and Wilson, J. (2004). Dynamics of growth and profitability in banking. Journal of Money, Credit and Banking 36, 1069-1090.

[32] Guest, P. M. (2009). The Impact of Board Size on Firm Performance: Evidence from the UK. European Journal of Finance, Vol. 15 (4), pp. 385-404.

[33] Hughes, J.P. and Mester, L.J. (1998). Bank capitalization and cost: evidence of scale economies in risk management and signaling. Review of Economics and Statistics 80, 314-325.

[34] Jaap, W. B., \& Bikker, A. J. (2014). Bank Performance: A Theoretical and Empirical Framework for the Analysis of Profitability, Competition, and Efficiency. https://www.researchgate.net/publication/46724029.

[35] Jensen, M., (1993). The modern industrial revolution, exit, and the failure of internal control system. Journal of Finance, 48, 831-880.

[36] Kagecha, K. P. (2014). Bank Performance: Does Bank Size Matter?. Research paper submitted to the School of Economics, University of Nairobi.

[37] Kasman, A. 2010. Consolidation and Commercial bank net interest margins: evidence from the old and new European union members and candidate countries. Economic Modeling 27. 648-655.

[38] Kasman, A., Carvallo, O. (2013). Efficiency and risk in Latin American banking: explaining resilience. Emerging Markets Finance and Trade, 49(2), 105-130.

[39] Khalfaoui, H., \& Ben Saada, M. (2015). The Determinants of Banking Performance: Empirical evidence from Tunisian Listed Banks. International Journal of Finance \& Banking Studies IJFBS ISSN: 2147-4486 Vol.4 No.2, 2015.

[40] Košak, M. and Zajc, P. (2006). "The East-West efficiency gap in European banking." In Balling M., Lierman F. and Mullineux A. (eds.): Competition and Profitability in European Financial Services. Strategic, systemic and policy issues." Routledge / SUERF, pp. 63-79.

[41] Kosmidou, K., Tanna, S. \& Pasiouras, F. (2005). «Determinants of Profitability of Domestic UK Commercial Banks: Panel Evidence from the Period 1995-2002», Money Macro and Finance (MMF) Research Group Conference 2005.

[42] Lipton, M. and Lorsch, J. W. (1992). A modest proposal for improved corporate governance, Business Lawyer, 48, 59-77.

[43] Liu, H., Wilson, J.O.S. (2010). The profitability of banks in Japan. Applied Finanial Economics, 20(24), 1851-1866.

[44] Makhokha, A. P. (2013). The Effect of Privatization on Financial Performance of Firm Listed at the Nairobi Securities Exchange. Research paper submitted to the School of Economics, University of Nairobi. 
[45] Molyneux, P., Thornton, J. (1992). The determinants of European Bank profitability. Journal of Banking and Finance, 16, 1173-1178.

[46] Murad, W. M., Alam, M. M. \& Hussien, E. M. (2014). The Performance of Islamic Banks during the 2008 Global Financial Crisis: Evidence from Gulf Cooperation Council Countries. https://papers.ssrn.com/sol3/papers.cfm?abstract_id=2517359.

[47] Naceur, S. \& Kandil, M. (2009). The impact of capital requirements on banks' cost of intermediation and performance: the case of Egypt. Journal of Economics and Business, 61, 70-89.

[48] Nippani, S., and K. W. Green. (2002). The Banking Industry after the Riegle-Neal Act: Restructure and Overall Performance. The Quarterly Review of Economics and Finance. 42(5), 901-909.

[49] Ongore, O.V., \& Kusa, B. G. (2013). Determinants of Financial Performance of Commercial Banks in Kenya. International Journal of Economics and Financial Issues Vol. 3, No. 1, 2013 , pp.237-252.

[50] Pasiouras, F. and Kosmidou, K. (2007). Factors influencing the profitability of domestic and foreign commercial banks in the European Union. International Business and Finance, 21, 222-237.

[51] Pasiouras, F., Molyneux, P., \& Loannidis, C., (2009). The Relationship between Bank Efficiency and Stock Returns: Evidence from Asia and Latin America. University of Bath, School of Management, Working Paper No. 2008. 10.

[52] Pradhan, S. R., \& Shrestha, R. (2016). Impact of Bank Specific and Macroeconomic Variables on the Performance of Commercial Banks of Nepal. https://papers.ssrn.com/sol3/papers.cfm?abstract id=2793530.

[53] Revell JRS (1980). Costs and margins in banking: an international survey. Paris: Organization for Economic Co-operation and Development.

[54] Royfaizal, R. C \& Fadzlan, S. (2008). Determinants of Bank profitability in a Developing Economy: Empirical Evidence from the Philippines. AAMJAF, Vol. 4, No. 2, 91-112, 2008.

[55] Saddique, A., Ahmad, M., Mumtaz. R., \& Arif, M. (2016). The Effect of Financial Variables on Bank Performance Pre and Post Financial Crisis. Journal of Finance and Accounting 2016; 4(6): 378-382.
[56] Sanchez, B., Hassan, K. M., Bartkus, J. R. (2013). Efficiency Determinants and Dynamic Efficiency Changes in Latin American Banking Industries. Journal of CENTRUM Cathedra: The Business and Economics Research Journal, 6, 27-52.

[57] Shelagh, H \& Maggie, F. (2008). The Determinants of Bank Performance in China. https://papers.ssrn.com/sol3/papers.cfm?abstract id=1247713.

[58] Smith, B. D., Levine, R., \& Smith, D. B. (2000). The Impact of Inflation on Financial Sector Performance. Working paper.

[59] Spathis Ch., Kosmidou K., \& Doumpos M. (2002). Assessing Profitability Factors in the Greek Banking System. International Transactions in Operational Research, Vol. 9, No. 5, 517-530.

[60] Srairi, S. A. (2009). Factors influencing the profitability of conventional banks and Islamic banks in GCC countries. Review of Islamic Economics, 13(1), 5-30.

[61] Terraza, V. (n. d). The effect of bank size on risk ratios: Implications of banks' performance. Working paper. Centre for Research in Economics and Management (CREA), University of Luxembourg.

[62] Togbenou, A., \& Combey, A. (2017). The Bank Sector Performance and Macroeconomics Environment: Empirical Evidence in Togo. International Journal of Economics and Finance Vol. 9, No. 2; 2017.

[63] Tomuleasa, L., \& Cocris, V. (2014). Measuring the Financial Performance of the European Systemically Important Banks. Working paper.

[64] Trabelsi, M. A. (2010). Governance and Performance of Tunisian Banks. International Journal of Economics and Finance.

[65] Tumin, H. M., \& Said, M. R. (2010). Performance and Financial Ratios of Commercial Banks in Malaysia and China. http://ssrn.com/abstract=1663612.

[66] Umar, M., Maijamai'a, D., \& Adamu, M. (2014). Conceptual exposition of the effect of inflation on bank performance. Journal of World Economic Research. Vol. 3, No. 5, 2014, pp. 55-59.

[67] Yermack, D. (1996). Higher market valuation of companies with a small board of directors. Journal of Financial Economics, 40, $185-212$. 